\title{
A GLOBÁLIS SZABADKERESKEDELEM KÖRNYEZETI ÉS ETIKAI PROBLÉMÁl
}

\section{ENVIRONMENTAL AND ETHICAL PROBLEMS OF GLOBAL FREE TRADE}

\author{
Fekete László \\ kandidátus, egyetemi docens, Budapesti Corvinus Egyetem \\ Ifekete@ella.hu
}

\begin{abstract}
ÖSSZEFOGLALÁS
Az 1972-ben rendezett első környezetvédelmi ENSZ Konferencia óta több ezer nemzetközi környezetvédelmi megállapodás született, amelyekben az államok kinyilvánították elkötelezettségüket a fenntartható fejlődés mellett. Ezeket a megállapodásokat nagyravágyó nyilatkozatok és szerény eredmények jellemzik. Sok érv szól amellett, hogy a környezetvédelmi célokat be kell építeni a nemzetközi kereskedelmi megállapodásokba. Annál is inkább szükséges a kereskedelem és a környezetvédelem ügyének egyesítése, mert a globális környezeti problémák jelentős része a természeti javak túlhasználatára és a költségek externalizálására épülő gazdaság működésére vezethető vissza. A nemzetközi kereskedelmi megállapodások ezt a feladatot nem végezték el. Bár hivatkoznak a fenntartható fejlődésre, mégis ezt a célt többnyire a bizonyítottan kudarcos gazdasági eszközök mozgósításával kívánják megvalósítani. A jelenlegi nemzetközi gazdasági és politikai helyzetben lehetetlennek tűnik kikényszeríthető környezetvédelmi szabályok integrálása a nemzetközi kereskedelem szabályrendszerébe.
\end{abstract}

\section{ABSTRACT}

Since the UN Conference on the Human Environment in 1972, thousands of international environmental agreements have been signed, in which states have agreed upon promoting sustainable development. Despite assiduous efforts, they are characterized by ambitious statements and modest results. There are several arguments that environmental objectives should be integrated into international trade regime. All the more so it became a necessity to integrate trade and environmental policies since operations of modern economy are based on the overuse of natural resources, and externalization of environmental costs goes with the erosion of nature. The recent international trade agreements fail to attain environmental objectives. Although the concept of sustainable development appears as the buzzword in these agreements, it merely relies on provenly failed economic tools. In the current international economic and political situation, it seems impossible to integrate enforceable environmental rules into the international trade regime.

Kulcsszavak: fenntarthatóság, gazdasági növekedés, nemzetközi környezetvédelmi és kereskedelmi szerződések, TPP, TTIP

Keywords: sustainability, economic growth, international environmental and trade agreements, TPP, TTIP 
Az ember természeti környezetéről 1972-ben rendezett ENSZ Konferencia óta 1311 többoldalú, valamint 2294 kétoldalú nemzetközi megállapodás született, amelyekben az aláíró felek kinyilvánították, hogy a természeti környezet megörzését kívánják előmozdítani (IEA Database Project, 2002-2017). A megállapodások bősége ellenére a természet állapotáért kinyilvánított közös felelősség többnyire nem párosult valóságos tettekkel, mérhető és ellenőrizhető eredményekkel. Az elfogadott kilencven alapvető nemzetközi megállapodás közül mindössze négy járult hozzá a természeti környezet állapotának a javulásához. A természeti környezet állapotához és a feladat nagyságához képest a megállapodások hatása csekély, eredményeik jelentéktelenek.

Valószínűleg ez lesz a sorsa a 2015-ös Párizsi Klímamegállapodásnak is. A 195 ország képviselői ugyan elfogadták azt, hogy a globális átlaghőmérséklet növekedését $2{ }^{\circ} \mathrm{C}$ vagy lehetőség szerint $1,5^{\circ} \mathrm{C}$ alatt tartják az iparosodás előtti szinthez képest, de az ENSZ Éghajlatváltozási Keretegyezményhez (UNFCCC) eljuttatott önkéntes nemzeti hozzájárulásaik nem elégségesek a cél teljesítéséhez (UNFCCC, 2016). Az aláírás óta már több kutatás állapította meg azt, hogy a benyújtott nemzeti hozzájárulások nincsenek összhangban a globális célokkal, sem a gyakran hangoztatott piac- és technológiavezérelt költséghatékony csökkentés koncepciójával. A nemzeti vállalások alapján a globális átlaghőmérséklet 2,6-3,1 ${ }^{\circ} \mathrm{C}$-os, más modellszámítások szerint 3,3-3,9 ${ }^{\circ} \mathrm{C}$-os emelkedése következik az évszázad végére (Wuebbles et. al., 2017). Az International Energy Agency becslése szerint a globális átlaghőmérséklet emelkedésének $2{ }^{\circ} \mathrm{C}$ alatti tartásához 2060-ra a teljes energiaszektornak el kellene érnie a zéró kibocsátást, a $1,5{ }^{\circ} \mathrm{C}$ alatti célhoz pedig 2040 -re kellene megvalósítania a karbonsemleges energiatermelést a földön.

\section{KERESKEDELEM ÉS KÖRNYEZET: WTO}

A környezetvédelmi megállapodások sikertelenségének okai számosak, de az egyik ok kétségtelenül az, hogy az aláíró felek többségének rövid távú politikai és gazdasági érdekeivel összhangban a megállapodások mögött álló intézményeket igen korlátozott jogkörökkel ruházták fel. A nemzetközi környezetvédelmi szabályok jelentős része „puha jog”, amelyekhez ellenőrző intézményeket és kényszerító intézkedéseket általában nem kapcsoltak. A puha jog rugalmasságot biztosít az államok számára saját körülményeikhez, gazdasági képességeikhez és technológiai fejlettségükhöz szabott környezetpolitikájuk kialakításához. A közös, de differenciált és képességek szerinti felelősség elvét emelik ki 1992 óta a nemzetközi környezetvédelmi megállapodások. Azonban ez az elv megnehezíti összehangolt és átfogó cselekvési program kialakítását, mert globális környezeti problémák kezeléséhez sokkal inkább a nemzeti környezetpolitikák, megengedő 
szabályozások és egyedi mentességek meghaladására lenne szükség. A differenciált és képességek szerinti felelősségre való hivatkozás pedig nem meggyőző, ha elvileg rendelkezésre állnak a képességek kiegyenlítésére szolgáló eszközök, amelyeket a nemzetközi környezetvédelmi megállapodások sohasem mulasztanak el felsorolni.

Sok érv szól amellett, hogy a környezetvédelmi célokat be kell építeni a nemzetközi kereskedelmi megállapodásokba. Annál is inkább szükségesnek tủnik a kereskedelem és a környezetvédelem ügyének az egyesítése, mert a globális környezeti problémák jelentős része a globális közjavak felélésére és a költségek externalizálására épülő gazdasági modell müködésére vezethető vissza.

Az 1994-es Marrákesi Egyezmény is utal arra, hogy a WTO-hoz (World Trade Organization, Kereskedelmi Világszervezet) csatlakozott államok a fenntartható fejlödéssel, a természeti környezet védelmével és megörzésével összhangban vesznek részt a nemzetközi kereskedelemben. Más szabadkereskedelmi megállapodások is hivatkoznak a multilaterális környezetvédelmi megállapodásokra, de a hivatkozáson túl nem konkretizálják azt, hogy mi lenne azokkal kapcsolatban a feladat. Tehát a nemzetközi környezetvédelmi megállapodások általában nem teremtenek olyan egységes és kikényszeríthető szabályokat, amelynek alapján szankcionálni lehetne a vállalatok vagy az államok normasértéseit. Ahogy Daniel Bodansky rámutatott, a megállapodásokban a természetre vonatkozó normák diszkurzív természetủek, amelyek azt mutatják, ahogy az államok egymással tárgyalnak, s nem azt, ahogy államok általában viselkednek (Bodansky, 1995, 115-116.).

Először az Európai Unió, Svájc és Japán képviselői javasolták az 1996. decemberi szingapúri miniszteri konferencián a WTO kereskedelmi és a környezetvédelmi szabályainak összehangolását. A Doha Development Round menetrendjéröl döntő konferencia 2001. novemberi határozatában is szerepelnek a környezetvédelem fontosságát hangsúlyozó megállapítások. Ugyanakkor a határozat megtiltotta új szabály megalkotását, amely a környezet védelmére hivatkozva korlátozná a kereskedelmet. A bizottság tagjai ,....nem adhatnak hozzá, s nem is vehetnek el a tagállamoknak az érvényes WTO-megállapodásokban lefektetett jogaiból és kötelezettségeiböl." (WTO, 2001, para 31i, 32.) A tárgyalásokon kialakult nézet megerősítette a szervezet ismert álláspontját: a környezetvédelem ügye nem változtathatja meg a kialakult jogi status quót, a környezetvédelmi megállapodások ajánlásai nem írhatják felül a WTO szabályait. A WTO honlapján a szervezet mandátumáról ma is az olvasható, hogy „,[a] WTO csak a kereskedelem ügyében illetékes. Más szóval, környezetvédelmi ügyekben az egyetlen feladata az, hogy azokat a kérdéseket tanulmányozza, amelyek akkor merülnek fel, amikor a környezetvédelmi politikák jelentős hatást gyakorolnak a kereskedelemre. A szervezet tagjai nem akarnak a nemzeti vagy nemzetközi környezetvédelmi politikákba beavatkozni vagy környezetvédelmi sztenderdeket felállítani.” (URL1) Röviden, 
a WTO a nemzetközi környezetvédelmi megállapodások kereskedelmi hatásaival s nem a nemzetközi kereskedelemnek a természeti környezetre gyakorolt hatásaival foglalkozik.

A mandátum kiterjesztéséhez hiányzik az a közösen vállalt politikai cél, amely a bürokratikus igazgatáson túl felhatalmazná a szervezetet arra, hogy a környezetvédelmet szolgáló döntéseket hozzon. A szervezet ideológiája továbbra is az, hogy a szabadkereskedelem a globális jólét legfőbb forrása, a fejlődés egyedüli elömozdítója, amely ráadásul még a környezetvédelem ügyét is képes hatékonyan szolgálni. Hitük szerint a gazdasági növekedés jóléti eredményeivel járó nagyobb környezetterhelést idővel majd ellensúlyozza a gazdaság dematerializálása, a technikai innováció és a környezettudatosság. Azonban az adatok azt mutatják, hogy a gazdasági növekedés továbbra is a természeti erőforrások kimerítésének és felélésének árán megy végbe (Boden et al., 2017).

A jelenlegi nemzetközi gazdasági és politikai helyzetben lehetetlen feladatnak tűnik az, hogy a WTO kikényszeríthető környezetvédelmi szabályokat integráljon a kereskedelem nemzetközi rendszerébe. Az persze nyitott kérdés, hogy más nemzetközi intézmények elégtelen teljesítménye miatt hasznosnak tartanánk-e azt, hogy a WTO mandátumán túlnyúló ügyekben, így például a környezetvédelem, a klímaváltozás, az emberi jogok vagy a munkajog ügyeiben a globális kormányzás legföbb intézménye és döntő fóruma legyen.

\section{MEGAREGIONÁLIS KERESKEDELMI MEGÁLLAPODÁSOK ÉS A KÖRNYEZET}

A gazdasági elemzések a WTO válságának, a globális gazdaság átalakulásának és növekedési kényszerének összefüggésében vizsgálják a két megaregionális szabadkereskedelmi megállapodást, a Trans-Pacific Partnershipet (TPP) és a Transatlantic Trade and Investment Partnershipet (TTIP). A TPP és a TTIP legfontosabb célja az volt, hogy olyan új szabályrendszert vezessen be, amely gazdasági, politikai és jogi eszközök alkalmazásával erga omnes, vagyis a nem társult országokra is kiterjed.

Bár Donald Trump a TPP-megállapodást felmondta, és a TTIP-tárgyalásokat befagyasztotta, talán érdemes közelebbröl megvizsgálni a két megállapodás környezetvédelmi fejezeteit. Teljesül-e a 2015. évi National Security Strategyben tett vállalás: ,a világ legmagasabb sztenderdjeit állítjuk fel a munkajogok és a környezetvédelem számára." (The White House, 2015, 17.) Vajon a TPP felmondását és a TTIP befagyasztását elszalasztott lehetőségként kell értékelnünk, vagy azok sikeres lezárása sem teremtett volna környezetvédelmi szempontból a jelenleginél kedvezőbb helyzetet? 


\subsection{TPP}

Az amerikai tárgyalási pozíciót kezdetben az elnök és a kongresszus két pártjának vezetői között 2007. május 10-én létrejött, a New Trade Policy for America címü dokumentumban lefektetett elvek határozták meg. A felek kinyilvánították, hogy az ország által ratifikált hét alapvető multilaterális környezetvédelmi megállapodás elöírásainak kötelező „,elfogadását, megtartását és végrehajtását” belefoglalják minden jövőbeni szabadkereskedelmi egyezménybe. A dokumentumban felsorolt és kiemelten fontosnak tartott környezetvédelmi megállapodások a következők voltak: a veszélyeztetett vadon élő állat- és növényfajok nemzetközi kereskedelméről szóló egyezmény (CITES), az ózonréteget lebontó anyagokról szóló Montreali Jegyzőkönyv, a tengerek elszennyeződésének megakadályozásáról szóló jegyzőkönyv (MARPOL), az amerikai államok közötti trópusi tonhal egyezmény (IATTC), a vizes élőhelyekről szóló ramsari egyezmény, a nemzetközi bálnavadászati egyezmény (IWC) és az Antarktisz tengeri élővilágának védelméről szóló egyezmény (CCAMLR). Az említett hét megállapodás mellett az Egyesült Államok bármely más környezetvédelmi megállapodás kötelezettségeit is kész kereskedelmi szerződésbe foglalni, ha a tárgyaló felek erről meg tudnak állapodni. Az amerikai kereskedelmi megbízott összefoglalója szerint a tárgyalókat arra is felhatalmazták, hogy a környezetvédelmi megállapodások megengedö, világos jogi fogalmakat kerülő nyelvezetét a kereskedelmi szerződésekben átfogalmazzák, nevezetesen, a „törekszik”-et (strive to) „kell”-re (shall) változtassák (USTR, 2007).

A felsorolt nemzetközi környezetvédelmi megállapodások a globális környezeti problémák kis részét ölelik fel, s nem történik hivatkozás például az UNFCCCre vagy a nemzetközi tengerjogi egyezményre (UNCLOS) sem. Ha a WTO szabályrendszerével vetjük össze, amely húsz alapvető nemzetközi környezetvédelmi megállapodás rendelkezéseivel kapcsolatban állapította meg, hogy azoknak alapvető hatásuk van a nemzetközi kereskedelemre, akkor a New Trade Policy for America környezetvédelmi szempontból kevés előremutató elemet tartalmaz. Mindamellett volt esély arra, hogy a TPP környezetvédelmi fejezete túllép a korábbi üres formulákon, a kötelező szabályokat és szankciókat gondosan kerülö előírásokon. S talán képes lett volna ezekben az új kereskedelmi megállapodásokban egyensúlyt teremteni a gazdasági érdek és a természeti környezet iránti felelősség között. Ennek némi esélyét látszott alátámasztani a 2015. május 22-én elfogadott Bipartisan Congressional Trade Priorities and Accountability Act is, amely a szabadkereskedelmi tárgyalásokon megvalósítandó környezetvédelmi célokat határozta meg.

A 2013. november 24-i, a TPP környezetvédelmi fejezetét tárgyaló bizottság kanadai elnöke által elöterjesztett fejezet az art. 20.15.-ben részletesen foglalkozott a klímaváltozással, s az energiahatékonyságtól a közlekedésen és az 
erdőgazdálkodáson át az üvegházhatású gázok kibocsátásának ellenőrzéséig felsorolta mindazon területeket, amelyekben a felek együttmüködni kívánnak. A tervezet külön kihangsúlyozta azt, hogy ,[a] felek elfogadják, hogy az éghajlatváltozás mint globális probléma kollektív fellépést igényel, s elismerik a UNFCCC és kapcsolódó jogi dokumentumaik alapján vállalt kötelezettségeik végrehajtásának a fontosságát" (TPP, 2013). Azonban a végleges TPP-megállapodás környezetvédelmi fejezetéből gondos kezek eltávolítottak minden hivatkozást és utalást a klímaváltozásra, a UNFCCC-re, valamint más nemzetközi környezetvédelmi megállapodás keretében az aláíró felek által is elfogadott rendelkezésekre. Amerikai és ausztrál javaslatra az art. 20.15.-öt alaposan lerövidítették, s eredetileg a klímaváltozáshoz alkalmazkodó gazdaság (climate change resilient economy) címből is kihagyták a klímaváltozást, homályban hagyva azt, hogy mit jelent az alkalmazkodó gazdaság. Persze a klímaváltozásnak mint valami tiltott varázsigének a végleges szövegből történő eltávolítása nem volt teljesen váratlan, hiszen az idézett 2015-ös törvény is úgy rendelkezik, hogy a tárgyalásokon ,...biztosítani kell, hogy a kereskedelmi megállapodások ne alapozzanak meg kötelezettségeket az Egyesült Államok számára az üvegházhatású gázok kibocsátásra vonatkozó intézkedések tekintetében...” (19 U.S.C. § 4201(a)(15)). Ez a feltétel pedig akkor teljesül, ha a megállapodásban egyáltalán nem esik szó klímaváltozásról.

A környezetvédelmi fejezet világos sztenderdek, szabályok és szankciók felállítása helyett a nemzeti szabályozások elsőségét emeli ki, s továbbra is az úgynevezett önkéntes mechanizmusoktól, például önkéntes ellenőrzéstől és beszámolókészítéstől, információ- és tudásmegosztástól és hasonló intézkedésektől várja a globális környezetvédelmi célok megvalósítását (TPP, 2015, Ch. 20.11 (1)). A nemzetközi környezetvédelmi megállapodások önkéntességre épülö „mechanizmusai" eleddig nem tudták megállítani vagy legalább enyhíteni a természeti környezet degradációját. Mivel a TPP környezetvédelmi fejezete jogi kötőerővel rendelkező kötelezettségek helyett továbbra is az önkéntesség elvére apellál, valószínüleg nem teremtett volna kedvezőbb helyzetet a korábbi állapotokhoz képest. Az aláírt megállapodásban a természeti környezet és a gazdasági tevékenység közötti újszerủ, kiegyensúlyozott vagy felelős kapcsolat értelmezéséhez kevés támpontot találunk.

Más elemzők a nemzetközi környezetpolitikában fennálló visszafogottságot nem klímaszkeptikus meggyőződésnek, hanem a mindenkori kormányzatok döntéseiben és tetteiben megjelenő bizalmi realista álláspontnak tulajdonítják. A bizalmi realista politikai-filozófiai felfogás szerint a kormányok a választóiktól kapják a felhatalmazást, velük szemben vannak politikai és morális kötelezettségeik, az ő jólétüket kell maximalizálniuk, és országuk érdekeit kell szolgálniuk. Arra azonban nem terjed ki megbízatásuk, hogy kötelezettségeket vállaljanak a globális közösség javára, és az ország gazdasági és pénzügyi erőforrásait globális 
célok előmozdítására használják fel. Az emberiség sorsáért aggódni és jövőjéért tenni nem része a választott tisztségviselők politikai mandátumának. Egyszóval minden olyan politikai döntés, amely globális környezeti problémák reparálása érdekében történik, illegitim.

\subsection{TTIP}

A jelenlegi amerikai kormányzat viszonya a nemzetközi környezetvédelmi megállapodásokhoz tankönyvszerủ példája ennek a bizalmi realista álláspontnak. Ezért az idézett határozatokban, törvényekben lefektetett kereskedelmi prioritások és környezetpolitikai elöírások ismeretében meglehetősen merész feltételezés lenne abban bízni, hogy a TTIP-tárgyalások folytatódni fognak, elő fogják mozdítani a globális környezetvédelem ügyét, s progresszív irányba terelik a gazdasági növekedés, a kereskedelem és a környezetvédelem kapcsolatát, s talán túlléphetnek a WTO erőtlen és diszfunkcionális szabályain.

Az Európai Unió az egyik fő kezdeményezője a nemzetközi környezetvédelmi megállapodásoknak, $\mathrm{s}$ rendszeresen állást foglal a fenntartható fejlődés, a környezetvédelem, a szabad és méltányos kereskedelem céljainak előmozdításáért. Ahogy a tagállamok lefektették a Lisszaboni Szerződésben (2007), az unió környezetpolitikai célja az, hogy ,...nemzetközi szinten előmozdítsa a regionális vagy világméretü környezeti problémák, s különösen az éghajlatváltozás elleni küzdelem kezelésére irányuló intézkedéseket" (EU, 2008, art. 191.). Az Európai Parlament a szerződésre hivatkozva több állásfoglalásban is kifejtette azt, hogy az Európai Unió környezetvédelemmel és a klímaváltozással kapcsolatos kereskedelempolitikai céljainak összhangban kell állniuk azokkal az alapelvekkel, amelyek a szervezet létrehozását, fejlődését és bővítését ösztönözték. Az emberi jogi, a társadalmi és a környezetvédelmi normák kiemelten fontosak az unió nemzetközi gazdasági és kereskedelmi kapcsolataiban, ezért azok jogi kötőerővel rendelkező részei kell hogy legyenek a szabadkereskedelmi megállapodásoknak is. Ahogy 2010. november 25-én az Európai Parlament állásfoglalásában megállapította: „....ameddig a kereskedelemre, a munkára vagy a környezetre vonatkozó multilaterális szabályok létrehozásának kilátásai a WTO keretén belül nem nagyon biztatóak", addig a kétoldalú kereskedelmi tárgyalások az Európai unió környezetpolitikai céljainak a legföbb fórumai (EP, 2010). A WTO bénultsága miatt az unió kétoldalú szabadkereskedelmi megállapodások megkötésével próbálja elérni azt, hogy a környezetvédelem és a fenntartható fejlődés idővel a multilaterális szabadkereskedelmi megállapodások részévé váljon.

A TTIP-tárgyalások 2011 végén kezdődtek az Egyesült Államok és az Európai Unió között. Közös közleményben foglalkoztak az elérendő célokkal, s külön kiemelték a pénzügyi stabilitás, valamint a hosszú távú és kiegyensúlyozott gazdasági növekedés fontosságát, de ezeket az elérendő célokat nem tárgyalták 
a globális környezeti problémák összefüggésében. Hivatkoztak ugyan a klímaváltozásra és a környezeti problémákra, s méltatták az ENSZ durbani és cancuni klímakonferenciáján elért eredményeket, amelyek egyébként nem voltak számottevőek, s ahol az Egyesült Államok, Kína és a többi nagy szennyező ország sikerrel akadályozta meg a Kiotói Jegyzőkönyv megújítását és kiterjesztését. A felek szándéka az volt, hogy a környezetvédelmi ügyek tárgyalását a nemzetközi környezetvédelmi fórumok keretén belül folytassák le. Más szóval, a TTIP-tárgyalások kezdetén a felek nem akartak teret adni a globális kereskedelem további növekedése miatt szükséges új környezetvédelmi kezdeményezések megvitatásának. Így a gazdasági növekedés, a globális kereskedelem környezetvédelmi hatásainak felvetése nemcsak a Párizsi Klímamegállapodás témái között nem kapott helyet, de kezdetben nem mutatkozott esély arra sem, hogy kellő hangsúllyal szerepeljen a TTIP-tárgyalások napirendjén.

A Párizsi Klímamegállapodás egyöntetü nemzetközi támogatásának a hatására a klímaváltozás és a globális kereskedelem bővülésének kérdésében az Európai Unió tárgyalási stratégiája a korábbiakhoz képest megváltozott. Az Európai Parlament 2015. július 8-i állásfoglalása is részletes listát tartalmaz, amelyet a tárgyalóknak követniük kell. Eszerint nemcsak a fenntarthatósági fejezetbe, hanem a megállapodás valamennyi fejezetébe, így például a beruházásokról, az energiáról és a szolgáltatásokról szóló fejezetbe is bele kell foglalni az unió környezetvédelmi céljait (EP, 2015, art. 2. (d) (iii)). Úgy vélték, hogy a Párizsi Klímamegállapodás politikai sikere megkönnyítette a felek között az együttmúködést a környezetvédelmet szolgáló közös kereskedelempolitika kialakításához. Ezért a tárgyalók kifejezetten a Párizsi Klímamegállapodás vállalásaira hivatkozva azt javasolták a 2016. július 11-15-i brüsszeli fordulón, hogy a TTIP-megállapodásba foglalják bele a felek elkötelezettségét egy alacsony szén-dioxid-kibocsátású és a klímaváltozást visszafordító fejlődési pálya mellett, s állapodjanak meg a gazdaságban végrehajtandó közös lépésekben, mivel a UNFCCC-hez eljuttatott önkéntes nemzeti hozzájárulások nem tárják fel részletesen azt, hogy az országok milyen konkrét gazdasági döntéseket és intézkedéseket rendelnek vállalásaikhoz. Az unió tárgyalói továbbá azt javasolták, hogy a Trade and Sustainable Development fejezet tartalmazza a megújuló energetikai beruházásokat, a környezetbarát technológiák kereskedelmét fékező vámok és nem vámjellegü korlátok lebontását, és a fosszilis üzemanyagok előállítására nyújtott állami támogatások fokozatos kivezetését. Míg korábbi környezetvédelmi javaslataikban az Európai Unió tárgyalói a szabályozáshoz való jogot hangsúlyozták, ezen a tárgyalási fordulón szoros együttmüködést szorgalmaztak az energiahatékonyságot előmozdító és a klímaváltozást visszafordító szabályok és közpolitikai intézkedések kialakításában is (EC, 2015, art. 3., art. 17.; EC, 2016a). Azonban a 2016. október 3-7-i New York-i tárgyalási forduló után kiadott szükszavú beszámolóból az derült ki, hogy az amerikai tárgyalók nem fogadták el az Európai Unió klíma- és környezetvédel- 
mi javaslatainak jó részét. Ahogy a beszámoló diplomatikusan fogalmaz: „Ezek a megbeszélések lehetővé tették az Európai Unió és az Egyesült Államok számára álláspontjaik közelítését és annak egyértelmü meghatározását, hogy nézeteik mely területeken állnak közel egymáshoz, és mely kérdésekben térnek el.” (EC, 2016b)

A TTIP-tárgyalásokról szóló utolsó érdemi közleményt az Európai Unió kereskedelmi biztosa és az Egyesült Államok kereskedelmi képviselöje 2017. január 17-én tette közzé az unió és a távozó adminisztráció nevében, amelyben megerősítették elkötelezettségüket a tárgyalások folytatása mellett. Donald Trump már a választási kampány során jelezte, hogy nem tekinti az ország számára irányadónak a WTO vagy más kereskedelmi megállapodás szabályrendszerét, és saját elképzelése szerint kívánja átalakítani a nemzetközi kereskedelem rendszerét (Trump, 2016). A 2017. évi amerikai National Security Strategy gazdaság- és környezetpolitikai programja világosan jelzi a jelenlegi kormányzat szándékait: „A túlzott környezetvédelmi és infrastrukturális szabályozás akadályozta az amerikai energiatermelést és az új infrastrukturális projektek fejlesztését. [...] A minisztériumok és ügynökségek meg fogják szüntetni a felesleges szabályokat, amelyek megfojtották a növekedést, növelték az amerikai vállalatok költségeit, akadályozták a kutatást-fejlesztést, gátolták a foglalkoztatást, és arra ösztönözték a vállalatokat, hogy a tengeren túlra költözzenek.” (The White House, 2017, 17.) Sajátos módon ennek az új kereskedelempolitikának az első áldozata éppen a napelem-behozatalra kivetett 30\%-os büntetővám volt (Reuters, 2018).

\section{3. ÖSSZEGZÉS}

Az antropocén kezdete óta a fosszilis energiahordozók égetése, az üvegházhatású gázok koncentrációjának növekedése, a talajerózió, a kiterjedt erdőirtások, a fajok kihalása, a földi légkör termikus egyensúlyának megbomlása kíséri a globális gazdaság szekuláris növekedését (Lewis-Maslin, 2015). A természeti környezet degradációja ellenére a társadalomtudományok a természet és az ember gazdasági tevékenységének kapcsolatát, a globális közjavak használatát, a környezeti igazságosság problémáját vagy a természet élő és élettelen dolgainak jogalanyiságát és a velük szembeni emberi felelősség kérdését hosszú időn keresztül nem tették vizsgálódások tárgyává. Az első átfogó természettudományos bizonyítékok nem gyakoroltak különösebb hatást a föáramú közgazdasági gondolkodásra sem. Ahogy Robert Solow Nobel-díjas közgazdász ezekre válaszolva fogalmazott: „A világ természeti eröforrások nélkül is jól megvan, így azok felélése csak esemény, s nem katasztrófa" (Solow, 1974, 11.). Eszerint a természet nem feltétele, hanem inkább korlátja a gazdaság és a jólét határtalan növekedésének. A közgazdaságtan hagyományosan a piaci mechanizmusoktól, a gazdasági tevékenység demateria- 
lizálásától és a technológiai fejlődéstől várja a környezeti problémák megoldását: mivel a nem megújuló természeti erőforrások kiaknázásának növekvő költségei a termelöket is és a fogyasztókat is helyettesítésre ösztönzik, ezért a piac az árrendszeren keresztül hatékonyan szabályozza azok helyettesítését. Ezzel szemben Nicholas Stern arra mutatott rá, hogy a globális közjavak lepusztítása, a természeti környezet masszív és folyamatos elszennyezése „a legnagyobb piaci kudarc, amit a világ valaha látott" (Stern, 2009, 7.). A klímaváltozás nagyságrendje és következményei más alapvető, a jólétre, a méltányosságra, az igazságosságra, a szabadságra és az alapvető jogokra vonatkozó etikai kérdéseket is támasztanak. Ezért Stern szerint a feladat az, hogy a közgazdaságtan analitikus eszközeit alkalmassá tegyük a klímaváltozás hosszú távú, a jelen és a jövő generációt érintő hatásainak elemzésére és a szükséges közpolitikai javaslatok megtételére (Stern, 2009, 144-149.).

Ezt a feladatot a nemzetközi környezetvédelmi megállapodások hiányosan, a megaregionális kereskedelmi megállapodások pedig egyáltalán nem végezték el. Bár kötelező toposzként az utóbbiakban is megjelenik a fenntartható fejlödés fogalma és az ígéret a változtatásra, ezt a célt azonban többnyire a jól ismert és bizonyítottan kudarcos gazdasági eszközök mozgósításával kívánják megvalósítani. Az nyilvánvaló, hogy az ökoszisztéma megújuló képességével összhangban álló gazdasági paradigma megalkotása rövid távon jelentős költséget, jóléti veszteséget okozna a társadalomnak. A bevett intézmények, közpolitikák, technológiák, szokások és gyakorlatok, életmódok és életformák nyomán kialakuló útfüggőség és bezáródáshatás megnehezíti a rendszerszintủ változtatást. Egyszóval, a múlt tudása és döntései gyakran zárják be a társadalmat rossz kimenetelü helyzetekbe.

\section{IRODALOM}

Bodansky, D. (1995): Customary (and Not So Customary) International Environmental Law. Indiana Journal of Global Legal Studies, 3, 1.

Boden, T. - Andres, B. - Marland, G. (2017): Global CO Emissions from Fossil-Fuel Burning, Cement Manufacture, and Gas Flaring: 1751-2014. http://cdiac.ess-dive.lbl.gov/ftp/ndp030/ global.1751_2014.ems

EC (2015): EU Textual Proposal: Trade and Sustainable Development. 6 November 2015. http:// trade.ec.europa.eu/doclib/docs/2015/november/tradoc_153923.pdf

EC (2016a): Trade Favouring Low-emission and Climate-resilient Development. 14 July 2016. http://trade.ec.europa.eu/doclib/docs/2016/july/tradoc_154800.pdf

EC (2016b): Report of the 15 th Round of Negotiations for the Transatlantic Trade and Investment Partnership. 21 October. 13. http://trade.ec.europa.eu/doclib/docs/2016/october/tradoc_155027. pdf

EP (2010): European Parliament Resolution of 25 November 2010 on Human Rights and Social and Environmental Standards in International Trade Agreements. Official Journal of the Euro- 
pean Union, 2012/C $99 \mathrm{E} / 31$. https://publications.europa.eu/en/publication-detail/-/publication/ d2f0acad-d81f-45ea-a4f5-8be514222c72/language-en

EP (2015): European Parliament Resolution of 8 July 2015 Containing the European Parliament's Recommendations to the European Commission on the Negotiations for the Transatlantic Trade and Investment Partnership (TTIP) (2014/2228(INI)) art.2.(d)(iii), http://www.europarl.europa. eu/sides/getDoc.do?pubRef=-//EP//NONSGML+TA+P8-TA-2015-0252+0+DOC+PDF+V0//EN

EU (2008): Treaty on European Union. Brussels, 15 April 2008. http://register.consilium.europa. eu/doc/srv?l=EN\&f $=$ ST $\% 206655 \% 202008 \% 20$ INIT

IEA Database Project (2002-2017): International Environmental Agreements Database Project. https://iea.uoregon.edu

Lewis, S. L. - Maslin, M. A. (2015): Defining the Anthropocene. Nature, 519, 171-180. https:// www.researchgate.net/publication/273467448_Defining_the_Anthropocene

Reuters (2018): Trump Imposes Steep Tariffs on Imported Solar Panels and Washing Machines. The Guardian, Tue 23 Jan. 2018. https://www.theguardian.com/environment/2018/jan/23/ trump-imposes-steep-tariffs-on-imported-solar-panels-and-washing-machines

Solow, R. (1974): The Economics of Resources or the Resources of Economics. American Economic Review, 64, 2, 1-14. https://www.researchgate.net/publication/4721852_The_Economics_of_ The_Resources_Or_The_Resources_of_Economics

Stern, $\bar{N}$. (2009): The Global Deal. New York: Public Affairs

The White House (2015): National Security Strategy. Washington, DC: The White House

The White House (2017): National Security Strategy. Washington, DC: The White House

TPP (2013): Environment Working Group Chairs: Environment Chapter for All 12 Nations. 24 November, http://wikileaks.org/tpp-enviro

TPP (2015): Trans-Pacific Partnership Agreement. Ch 20: Environment

Trump, D. (2016): Contract with the American Voter: What Follows Is My 100-day Action Plan to Make America Great Again. https://assets.donaldjtrump.com/_landings/contract/O-TRU102316-Contractv02.pdf

UNFCCC (2016): Report of the Conference of the Parties on Its Twenty-first Session. Held in Paris from 30 November to 13 December 2015. FCCC/CP/2015/L.9/Rev.1. https://unfccc.int/ resource/docs/2015/cop21/eng/10.pdf

USTR (2007): Bipartisan Trade Deal. May 10. https://ustr.gov/sites/default/files/uploads/factsheets/2007/asset_upload_file127_11319.pdf

WTO (2001): Ministerial Declaration. 20 November 2001, WT/MIN(01)/DEC/1 https://docs.wto. org/dol2fe/Pages/FE_Search/FE_S_S009-DP.aspx?language $=$ E\&CatalogueIdList $=37246 \&$ CurrentCatalogueIdIndex $=0 \&$ FullTextSearch $=$

Wuebbles, D. J. et al. (2017): Climate Science Special Report: Fourth National Climate Assessment, Volume I. Washington, DC: USGCRP, https://science2017.globalchange.gov/downloads/ CSSR2017_FullReport.pdf

URL1: https://www.wto.org/english/thewto_e/whatis_e/tif_e/bey2_e.htm 